\title{
The effect of Alcoholic plant (tribulus terrestris) extract on the bacteria isolated from genital tract of infertile cows in vitro
}

\author{
M.S.Qasem A.M.Al-shawii L.Y. A.Al Rahman \\ Coll. of Vet. Med./ Unive. of Baghdad
}

\begin{abstract}
Out of Two hundred swabs collected from genital tract of infertile cows during the period between7/1/2012 to 30/6-2012. Cultured on Blood agar, Nutrient agar, MacConkey agar and Mannitol salt agar. 195 swab represented (97.5\%) give positive result and 5 swab (2.5\%) give negative result. from the positive culture 78 isolated (39\%) mixed bacterial infection. All bacteria isolates were identified by using different biochemical tests and API-20E, the single bacterial isolation in this study were Esherichia coli $41.8 \%$, Staphylococcus aureus $36.8 \%$, Pseudomonas aeruginosa $17 \%$, Citrobacter braakii $1.7 \%$, Providencia rettergi $1.7 \%$ and Shewanella putrefaciens $0.9 \%$. In mixed bacterial isolation, the highest percentage was 53.8\% Staphylococcus + Esherishia coli aureus and the lowest percentage was $1.3 \%$ Esherishia coli + Citrobacter braakii + Pseudomonas aeruginosa. Antibiotic susceptibility test were carried out on bacterial isolates using 10 single antibiotic discs of commonly used drug, the test showed that most bacterial isolated resist for most antibiotics (Amikacin, Amoxicillin, Nalidix acid, (Amoxicillin and Clavulanic acid), Cefixime, Ceftriaxone, Tetracycline, Nitrofurantoin, Norfloxacin and Gentamycin) on the other hand observed sensitive for alcoholic plant tribulus terrestris extract (fruit) in different concentrations
\end{abstract}

\section{Introduction}

Most cattle producers probably do not realise the extent of economic loss that can occur through reproductive failure in their cattle. Low calving rates may be due to infertility (failure of cows to conceive) or to early embryonic losses, abortion and stillbirth (1). Uterine function is often compromised in cattle by bacterial contamination of the uterine lumen, and pathogenic bacteria often persist, causing uterine disease, a key cause of infertility in cattle (2). Non- specific and specific bacteria are important causes of infertility in the cow. Uterine infections reduce the reproductive efficiency of cows and the profit potential of dairy Farms, uterine infections are difficult to prevent especially during calving (3). Herbal remedies used in folk medicine

\section{Material and methods}

1- Sample Collection: 200 swabs collected from the genital tract (cervix and uterus) of infertile cows, in the Abu-Ghraib and its adjacent area. After restraining the animal and securing its tail, the perineal region provide an interesting and still largely unexplored source for the creation and development of potentially new drugs for chemotherapy which might help overcomes the growing problem of resistance and also the toxicity of the currently available commercial antibiotics (4). Tribulus terrestris is an annual plant belonging to the family zygophllaceae, its summer growing medicinal plant now has worldwide distributions which include warm regions of Asia, Africa, Europe, America and Australia. It used in folk medicine as tonic, aphrodisiac, analgesic, astringent, stomachic, anti-hypertensive, diuretic, lithon-triptic and urinary anti-infective Also used for the treatment of cardiovascular disease $(5 ; 6)$.

cleared by washing and disinfectant. After that preparation tool for swabs obtained using a sterile double guarded swabs device which inserted through the vagina into the lumen of the cervical canal, guided by 
palpation per rectum. The inner rod of the catheter was then pushed forward to expose the swab and rotated four times against the mucosa. While moving the swab backward and forward, and then withdraw within the catheter under rectal guidance. All swabs transported to the laboratory in the appropriated media for bacteriology at $4{ }^{\circ} \mathrm{C}$, within 3-18 hours and according to (7).

2- Bacterial isolation: According to (8) Specimens for bacterial cultures were transferred from genital tract of cows into the transport media by aseptic swabbing. Each cervical and uterus swabs caltivated on Nutrient agar and Blood agar media aerobically and Microaerophilic at $37^{\circ} \mathrm{C}$ to promote growth of bacteria. Then transferred on Eosin methylene blue agar, MacConkey agar and Mannitol salt agar, isolation and identification of bacteria based upon Gram's staining colonial morphology biochemical tests and EPI 20 E for diagnosis of gramnegative bacteria.

3- Antibiotics susceptibility test: According to (9) plates were prepared with Muller - Hinton Agar, 3-4- similar colonies were selected to prepare pure culture, these colonies were transferred into about $5 \mathrm{ml}$ of nutrient broth incubated at $37 \mathrm{C}^{\circ}$ for $2-8 \mathrm{hrs}$ until light to moderate tubidity develops, turbidity adjusted by using MacFarland tube to $\left(1.5 \times 10^{8}\right) \mathrm{cfu} / \mathrm{ml}$ Dipasterile non toxic cotton swab on a wooden applicator into the standardized inoculums and rotate the soaked swab firmly against the upper inside wall of the tube to express excess fluid, streak the surface of the plate with the swab three times, allow the inoculums to dry for 5-15 minutes with lid in place, antibiotics discs which include (Amikacin, Amoxicillin, Amoxicillin and , Clavulanic acid,

\section{Result and discussion}

Biochemical tests result: The isolates can be biochemically distinguished from the unknown species and confirm the specific characteristics of each bacterial isolate. Furthermore, tables (1) and (2) showed the results of some biochemical tests diagnostic
Cefotaxime, Ceftriaxone, Gentamycin, Nalidix acid, Nitrofurantoin, Norfloxacin and Tetracyclin) these disc were fixed by using aseptic technique and then incubated immediately at $37 \mathrm{C}^{\circ}$ and examine after $24 \mathrm{C}^{\circ}$, the complete inhibition zone was recorded and compared with standard tables.

4- Preparation of alcoholic extract of Tribulus terrestris: It was done according to (10), Fifty grams of the fruit of tribulus terrestris powder were extracted with 500 $\mathrm{mL}$ of $70 \%$ ethanol under continuous stirring for eight hours at room temperature, the suspension was filtered by Whatman no. 0.22 filter paper and the filtrate was concentrated using vacuum rotary evaporator. The crud extract was stored in dark sterile screw bottle at $4 \mathrm{C}^{\circ}$ until use to prepare the required concentration.

5- Detection of Active compounds of tribulus terrestris $\mathrm{L}$ : Which including ATannins B- Flavonoids C- Saponins DAlkaloids E- Terepenes and steroids according to (11)

6- Antibacterial activity of alcoholic extract of tribulus terrestris in vitro: Used agar - well diffusion method according to (12), by inoculation of nutrient agar with (0.1) ml bacterial suspension which was spread by the sterile spreader, wells with diameter $(6 \mathrm{Mm})$ made on the surface of the nutrient agar plate using a sterile cork borer, (0.1) $\mathrm{ml}$ of different concentrations $(100,50$, $25,12.5,6.25,3,1.5,0.75 \mathrm{mg} / \mathrm{ml})$., were poured in the wells, one well used as a control and filled with $(0.1) \mathrm{ml}$ of sterile distilled water, the plates were incubated up down at $37 \mathrm{C}^{\circ}$ for (24) hours, the activity of the extract limited by measurement of inhibition zone in $(\mathrm{Mm})$ around each well. and differential to isolated bacteria. It has been possible to develop a practical laboratory test based on the characterized biochemical activities and can be devised a diagnostic strategy for the specified species of a bacteria. 


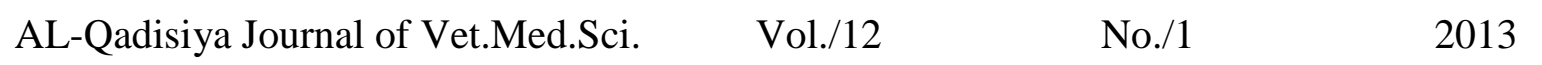

Table (1) Biochemical tests result for gram negative isolated bacteria.

\begin{tabular}{|c|c|c|c|c|c|c|c|c|c|c|c|}
\hline \multirow{2}{*}{$\begin{array}{l}\text { Types of } \\
\text { isolate } \\
\text { bacteria }\end{array}$} & \multirow{2}{*}{$\begin{array}{c}\text { Lactose } \\
\text { fermentation } \\
\text { macConkey }\end{array}$} & \multirow{2}{*}{ : } & \multirow{2}{*}{ o } & \multirow{2}{*}{ } & \multirow{2}{*}{ 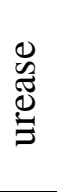 } & \multirow{2}{*}{ 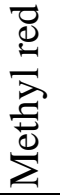 } & \multirow{2}{*}{ 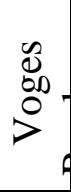 } & \multicolumn{3}{|c|}{ TSI } & \multirow{2}{*}{ 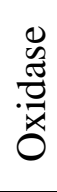 } \\
\hline & & & & & & & & Gas & $\begin{array}{l}\mathrm{H}_{2-} \\
\mathrm{S}\end{array}$ & reaction & \\
\hline $\begin{array}{l}\text { Escherichia } \\
\text { coli }\end{array}$ & $\mathrm{LF}$ & + & + & - & - & + & - & + & - & A/A & - \\
\hline $\begin{array}{l}\text { Pseudomonas } \\
\text { aeruginosa }\end{array}$ & NLF & + & - & + & V & - & - & - & - & ALK/ALK & + \\
\hline $\begin{array}{l}\text { Providencia } \\
\text { rettergi }\end{array}$ & NLF & + & + & + & + & + & - & + & - & A/ALK & - \\
\hline $\begin{array}{l}\text { Citrobacter } \\
\text { braakii }\end{array}$ & NLF & + & - & + & + & + & - & + & + & $\mathrm{A} / \mathrm{A}$ & - \\
\hline $\begin{array}{l}\text { Shewanella } \\
\text { putrefaciens }\end{array}$ & NLF & - & - & - & - & + & - & + & + & $\mathrm{A} / \mathrm{A}$ & - \\
\hline
\end{tabular}

$\mathrm{V}=$ variable reaction between species, $\mathrm{NLF}=$ no lactose fermentation, $-=$ negative, $+=$ positive, $\mathrm{a}=$ acid, Alk= Alkaine reaction.

Table (2) The result of biochemical tests for gram positive isolate bacteria.

\begin{tabular}{|c|c|c|c|c|c|}
\hline Isolate bacteria & $\begin{array}{c}\text { Mannitol } \\
\text { salt agar }\end{array}$ & Motility & Catalase & Coagulase & $\begin{array}{c}\text { Gelatin } \\
\text { liquification }\end{array}$ \\
\hline $\begin{array}{c}\text { Staphylococcus } \\
\text { aureus }\end{array}$ & + & - & + & + & + \\
\hline
\end{tabular}

The results of biochemical tests by using and more accurate diagnosis of most of the Api-20E system: The Api-20E system is gram negative bacteria as show in table (3). one of the most important diagnostic tests

Table (3): Api-20E system for diagnosis of gram- negative bacteria.

\begin{tabular}{|c|c|c|c|c|c|}
\hline Api-20E & $\begin{array}{c}\text { Pseudomonas } \\
\text { aeruginosa }\end{array}$ & $\begin{array}{c}\text { Escherichia } \\
\text { coli }\end{array}$ & $\begin{array}{c}\text { providencia } \\
\text { rettergi }\end{array}$ & $\begin{array}{c}\text { citrobacter } \\
\text { braakii }\end{array}$ & $\begin{array}{l}\text { Shewanella } \\
\text { putrefaciens }\end{array}$ \\
\hline ONPC & - & - & - & - & - \\
\hline $\mathrm{ADH}$ & + & - & - & + & - \\
\hline LDC & - & + & - & + & - \\
\hline ODC & - & + & - & - & + \\
\hline CIT & + & - & + & + & - \\
\hline $\mathrm{H} 2 \mathrm{~S}$ & - & - & - & + & + \\
\hline URE & - & - & + & + & - \\
\hline TDA & - & - & + & + & - \\
\hline IND & - & + & + & - & - \\
\hline $\mathrm{VP}$ & - & - & - & + & - \\
\hline GEL & + & - & - & + & + \\
\hline GLU & - & + & + & + & - \\
\hline MAN & - & + & + & + & - \\
\hline $\mathrm{NO}$ & - & - & + & - & - \\
\hline SOR & - & + & - & + & - \\
\hline RHA & - & + & + & + & - \\
\hline SAC & - & + & - & - & - \\
\hline MEL & - & + & - & - & - \\
\hline AMY & - & - & - & + & - \\
\hline ARA & - & + & - & + & - \\
\hline $\mathrm{OX}$ & - & - & - & - & - \\
\hline
\end{tabular}




\section{$\begin{array}{llll}\text { AL-Qadisiya Journal of Vet.Med.Sci. } & \text { Vol./12 } & \text { No./1 }\end{array}$}

The results of bacterial isolation: The results appear isolation of different bacteria from genital tract of infertile cows 195 swabs origin of 200 swabs $(97.5 \%)$ and 5 swab $(2.5 \%)$ have nogrowth. The samples give positive results for isolation include 117 single isolates $(58.5 \%)$, 78 mixed isolates $(39 \%)$. The bacterial isolates including five genera of gram negative bacteria which are Escherichia coli represent the highest percentage of bacterial isolate $(41.8 \%)$, Pseudomonas aeruginosa $(17 \%)$, while Citrobacter braakii and providencia rettergi have the same ratio $(1.7 \%)$ also Shewanella putrefaciens $(0.9 \%)$ and one gram positive bacteria which is Staphylococcus aureus in a percentage of $(36.8 \%)$ as shown in the table (4).

Table (4) Species numbers and percentage of single bacterial isolates from genital tract of infertile cows.

\begin{tabular}{|c|c|c|}
\hline Types of bacteria isolates & $\begin{array}{c}\text { number of isolated bacteria } \\
200\end{array}$ & percent $\%$ \\
\hline Escherichia coli & 49 & 41.8 \\
\hline Staphylococcus aureus & 43 & 36.8 \\
\hline pseudomonas aeruginosa & 20 & 17 \\
\hline Citrobacter braakii & 2 & 1.7 \\
\hline providencia rettergi & 2 & 1.7 \\
\hline Shewanella putrefaciens & 1 & 0.9 \\
\hline Total & 117 & $99.9 \%$ \\
\hline
\end{tabular}

In mixed isolation, (Staphylococcus aureus + Esherishia coli) isolated in highest percentage $53.8 \%$, followed by (E. coli + Pseudomonas aeruginosa) $11.5 \%$, (Esherishia coli + Pseudomonas aeruginosa \&Staphylococcus aureus) $10 \%$. (Staphylococcus aureus + Pseudomonas aeruginosa) $6.4 \%$, (Esherishia coli + Citrobacter braakii) 5.1\%, (Esherishia coli + Providencia rettergi) $3.8 \%$, while the lowest percentage were $1.3 \%$ for each of (Citrobacter braakii + Pseudomonas aeruginosa), (Providencia rettergi + Staphylococcus aureus), (Citrobacter braakii + Staphylococcus aureus + Pseudomonas aeruginosa), (Esherishia coli + Staphylococcus aureus + Citrobacter braakii) and (Esherishia coli + Citrobacter braakii + Pseudomonas aeruginosa); as shown in the tables (5).

Table (5) Species Numbers and percentage of mixed bacterial isolates from genital tract of infertile cows.

\begin{tabular}{|c|c|c|}
\hline Types of bacteria isolation & $\begin{array}{l}\text { number of isolated bacteria } \\
200\end{array}$ & $\begin{array}{c}\text { percent } \\
\%\end{array}$ \\
\hline Staphylococcus + Esherishia coli aureus & 42 & 53.8 \\
\hline Esherishia coli + Pseudomonas aeruginosa & 9 & 11.5 \\
\hline $\begin{array}{l}\text { Esherishia coli }+ \text { Pseudomonas aeruginosa }+ \text { Staphylococcus } \\
\text { aureus }\end{array}$ & 8 & 10 \\
\hline Staphylococcus aureus + Pseudomonas aeruginosa & 5 & 6.4 \\
\hline Esherishia coli + Citrobacter braakii & 4 & 5.1 \\
\hline Esherishia coli + Providencia rettergi & 3 & 3.8 \\
\hline Citrobacter braakii + Pseudomonas aeruginosa & 2 & 2.7 \\
\hline Providencia rettergi + Staphylococcus aureus & 2 & 2.7 \\
\hline $\begin{array}{l}\text { Citrobacter braakii }+ \text { Staphylococcus aureus }+ \text { Pseudomonas } \\
\text { aeruginosa }\end{array}$ & 1 & 1.3 \\
\hline Esherishia coli + Staphylococcus aureus + Citrobacter braakii & 1 & 1.3 \\
\hline Esherishia coli + Citrobacter braakii + Pseudomonas aeruginosa & 1 & 1.3 \\
\hline Total & 78 & $99.9 \%$ \\
\hline
\end{tabular}


Escherichia coli are the most common bacteria isolated from the uterine cavity of healthy cows and cows that develop disease of the uterus. $(13 ; 14)$ This result agreed to our study, also (15) in Iran (16) isolate E.coli in same percentage. The other studies refer to low percentage of isolation $(8 ; 17)$; In Iraq (18) isolated E.coli from cows suffering from inflammation of the endometrium of the uterus $(27.4 \%)$ and from vaginal secretions (19.2\%). Recently, it was observed that a specific E. coli causes uterine disease, which is different from known diarrhoeic or extra-intestinal pathogenic E. coli. This specific E. coli was named endometrial pathogenic $E$. coli (EnPEC). EnPEC was found to be more adherent and invasive to endometrial cells (13). The second bacteria isolated from genital tract of infertile cows were Staphylococcus aureus in a percentage of $(36.8 \%)$ and this result agreed with $(8 ; 16)$. And disagreed with (19) because they isolated these bacteria in lower percentage. Staphylococcus aureus is pathogens that are part of the normal microflora inhabitants of the skin and mucous membranes, including the genital tract of cow or present in wide range of the environment that bacteria are able to spread hematogenously to the fetoplacental unit and cause abortion with other bacterial pathogens such as Escherichia coli, Bacillus spp. and Pseudomonas spp. (19). The third isolate in percent study was Pseudomonas aeruginosa in a percentage of $(17 \%)$ which were the same percentage same percentage isolated from cases of repeat breeding and uterine infections in dairy cows by (8). While (20) and (16) isolated these bacteria in a higher percentage. Also (20) Isolated Pseudomonas aeruginosa from the oviduct and uterus of Iraqi cows. In Iraq (17) isolated the same bacteria from cows suffering from inflammation of the endometrium of the uterus and from vaginal secretions. Citrobacter braakii and providencia rettergi represent the low percentage of isolates
(1.7\%) for each one. (21) Able to isolate Citrobacter from the uterus of cows and foetal membrane In Iraq Citrobacter was isolated from uterus of cows and buffalo by (22) in percentage agreed to the percentage of isolation of this study. Whereas (23) mention providencia rettergi is consider high potential pathogenicity of uterine infection (endometritis) in bovine followed Staphylococcus aureus (Coagulase + ) than Escherichia coli. Shewanella putrefaciens isolated in this study in very low percentage $(0.9 \%)$ and the pathogenic role of this agent remains largely undefined (24). Non specific bacteria consider the most common cause of uterine infection and are the pathogenic microorganisms affecting productivity and fertility of cows $(25 ; 26)$. Pathogenic organisms isolated from an infected uterus are found generally in livestock environments and are capable of infecting other tissues and organs (27). Numerous bacteria in a variety of combinations have been isolated from infected uterus (21). Embryonic mortality has a substantial impact on the fertility of bovine. Most of the embryonic losses occur during the first days after fertilization and during the process of implantation. Nonspecific pathogens are mainly bacteria that enter the uterus by ascending infection; uterine pathogens may cause embryonic mortality by changing the uterine environment or by a direct cytolytic effect on the embryo. (28).

The results of antibiotic susceptibility test: Susceptibility test showed that most isolates of bacteria which were isolated from infertile cow resist to most antibiotics used as follows: Esherishia coli resistant $100 \%$ to Amikacin, Nalidix acid. Amoxicillin.(Amoxicillin and Clavulanic acid), Cefixime, Ceftriaxone and Tetracycline $80 \%$. Nitrofurantoin and Norfloxacin $\quad 60 \%$. Gentamycin $50 \%$.Staphylococcus aureus resist $100 \%$ for each of Amikacin and Nalidix acid. Amoxicillin, Cefixime and Tetracycline 

AL-Qadisiya Journal of Vet.Med.Sci.
Vol./12
No./1
2013

90\%.Gentamycin and Norfloxacin 80\%. (Amoxicillin and Clavulanic acid), Ceftriaxone and Nitrofurantoin 70\%.Pseudomonas aeruginosa resistant $100 \%$ to all types of antibiotics with exception to Gentamycin and Nitrofurantoin 90\%. Ceftriaxone $80 \%$. Citrobacter braakii resist $100 \%$ of Amikacin, Amoxicillin, Cefixime, and Tetracycline. While (Amoxicillin and Clavulanic acid), Ceftriaxone, Nalidix acid, Nitrofurantoin and Norfloxacin

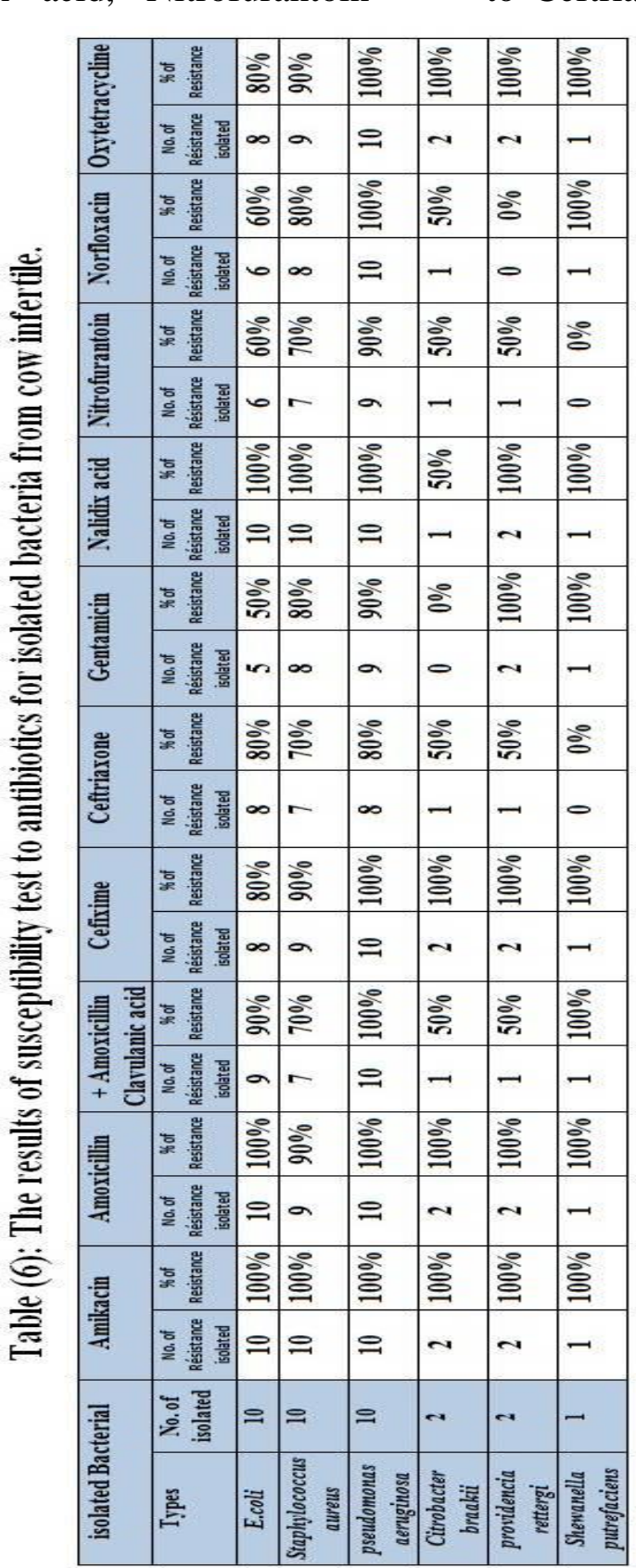

50\%; but sensitive to Gentamycin. Providencia rettergi resist $100 \%$ the most antibiotic except (Amoxicillin and Clavulanic acid), Ceftriaxone and Nitrofurantoin 50\%. And sensitive to Norfloxacin. Also Shewanella putrefaciens resist $100 \%$ the most antibiotic, Amikacin, Amoxicillin, (Amoxicillin and Clavulanic acid), Cefixime, Gentamycin, Nalidix acid, Norfloxacin and Tetracycline but sensitive to Ceftriaxone and Nitrofurantoin, as show in the table (6). 


\section{$\begin{array}{llll}\text { AL-Qadisiya Journal of Vet.Med.Sci. } & \text { Vol./12 } & \text { No./1 }\end{array}$}

Application of antibiotics in veterinary medicine for more than 50 years had a major impact on microbial communities, resulting in an enrichment of bacterial populations which were resistant to, or developed or acquired resistance to, the antibiotics used; therefore it's essential to know the susceptibility and resistance of antimicrobial agents available for the principal pathogens isolated from the uterus. $(29 ; 30)$. Gentamicin is now widely used as the treatment of choice for many serious Gramnegative infections, so increase in resistance was specific and nonspecific; nonspecific mean the some of the bacterial enzymes are unaffected due to inactivate gentamicin (31) - The recent studies refer that bacterial resistance to aminoglycosides including amikacin are the most resistance to the action of bacterial modifying enzymes such as in E.coli (32). These results of the current study agree with (33) who that mention the most antimicrobial multidrug-resistant $\mathrm{E}$. coli was isolated from uterine dairy cows. Oxytetracycline was already widely used for the treatment of uterine infection in dairy cattle and as prophylaxis after caesarian section, whereas Oxytetracycline is widely used for the treatment of uterine infection in dairy cattle, there was evidence of resistance in most of the bacteria (27). Added amoxicillin has been largely used in veterinary medicine. All forms of livestock around the world are treated with it, alone or in combination with clavulanic acid, determined the antibacterial resistance of $E$. coli and staphylococcus spp.; also all Pseudomonas aeruginosa isolates were resistant to amoxicillin-clavulanic acid the same of most antimicrobial used in current study (34).

The results of antimicrobial activity of Tribulus terrestris: The result shows that tribulus terrestris extracts of different concentrations were able to inhibit the growth of isolated microorganisms from genital tract of infertile cow which include Escherichia coli, Pseudomonas aeruginosa, Citrobacter braakii, Providencia rettergi and Shewanella putrefaciens and Staphylococcus aureus as show in the table (7).

Table (6) The result of plant susceptibility test

\begin{tabular}{|c|c|c|c|c|c|c|c|c|}
\hline \multirow{2}{*}{\begin{tabular}{|l} 
Isolated bacteria \\
tribulus terrestris
\end{tabular}} \\
& \multicolumn{7}{|l|}{ Inhibition } \\
& of \\
& 100 & 50 & 25 & 12.5 & 6.25 & 3 & 1.5 & 0.75 \\
\hline Escherichia coli & 35 & 31 & 27 & 23 & 20 & 16 & 13 & 11 \\
\hline Staphylococcus aureus & 30 & 26 & 23 & 18.5 & 15 & 11 & 9 & 6 \\
\hline Pseudomonas aeruginosa & 23.5 & 21 & 18 & 15 & 11 & 8 & 5 & 2 \\
\hline Citrobacter braakii & 37 & 34 & 31 & 27 & 23 & 22 & 18 & 13 \\
\hline Providencia rettergi & 32 & 27 & 22 & 19 & 16 & 12 & 8 & 5 \\
\hline Shewanella putrefaciens & 29 & 24 & 21 & 18 & 16 & 12 & 7 & 4 \\
\hline
\end{tabular}

The activity of the plant against both Gram positive and Gram-negative bacteria may be indicative to the presence of broad spectrum antibiotic compounds or simply general metabolic toxins in the plant, in addition to the plant (fruits) content of pharmacological active metabolites like saponins (35) Saponins have been reported to possess a wide range of biological activities. The toxicity of Saponins to insects (insecticidal activity), parasite worms (anthelmintic activity), and their antifungal, antiviral, and antibacterial activities are well documented (36). The mode of action of antibacterial effects of saponins seems to involve membranolytic properties, rather 
$\begin{array}{llll}\text { AL-Qadisiya Journal of Vet.Med.Sci. } & \text { Vol./12 } & \text { No./1 }\end{array}$

than simply altering the surface tension of the extracellular medium, thus being influenced by microbial population density $(37 ; 38)$. Flavonoids are known to be synthesized by plants in response to microbial infection. Their activity is probably due to their ability to complex with extracellular and soluble proteins and to complex with bacterial cell walls (39). More lipophilic flavonoids may also disrupt microbial membranes (40). Alkaloids isolated from plant are commonly found to have antimicrobial properties (41). Berberine and harmane are important representatives of the alkaloid group. The mechanism of action of berberine and harmane is attributed to their ability to intercalate with DNA (42).
1. Wathes, D. C.; Brickell, J. S.; Bourne, N. E.; Swalia, A. And Cheng, Z. (2008)Factors influencing heifer survival and fertility on commercial dairy farms. Journal Animal.2:8, pp $1135-1143$.

2. Sheldon, M.; Gregory, S.; Stephen, L.; Robert, O. (2006) Defining postpartum uterine disease in cattle, Theriogenology 65; 1516-1530.

3. G. S. (1997) Lewis Symposium: Health Problems of the postpartum cow; Journal of Dairy Science Vol. 80, No. 5, 984-994.

4. Kianbakht S. and Jahaniani F. (2003). Evaluation of Antibacterial Activity of Tribulus terrestris L. Growing in Iran. Iranian journal of pharmacology \& therapeutics 2:2224.

5. Usman, H. F. I.; Abdulrahahman and Ladan, A.A. (2007). Pytochemical and antimicrobial evalution of Tribulus terrestris L. (Zygophyllaceae) growing in Nigeria. Research journal of Biological Sciences. 2(3), Pp.244247.

6. Yajuan, X.; Yonghong, L.; Tunhai, X. ; Shengxu, X.; Yunshan, S.; Yue; L., Haiou; Z., Tonghua, L. and Dongming, X.(2010). A New Furostanol Glycoside from Tribulus terrestris; Molecules Vol: 15; 613618.

7. Ata, Ayhan; Hülya, Türütoğlu; Mehmet, K.; Mehmet, S.Gülay and Faruk, P. (2010).Microbial Flora of Normal and Abnormal Cervical Mucous Discharge Associated with Reproductive Performance of Cows and Heifers in Estrus, Asian-Aust. J. Anim. Sci.; Vol.23; No. 8: 10071012.

8. Gani, M. O.; Amin, M. M.; Alam, M. G. S.; Kayesh, M. E. H.; Karim, M. R; Samad,M. A.and Islam, M. R.(2008) Bacterial flora associated with repeat breeding and uterine infections dairy cows, Bangl. J. Vet. Med.6 (1): 79-86.

9. Bauer, A.W.; Kirbay, W.A.; Sherris, J.S. and Turk, M.(1966). Antibiotic susceptibility testing by standardized single disc method. AMJ. Clin. Patholo.; 45:493-496.

10. Montmat, L. A.; Fag, C.A. and Petra, O. M. (1982) .Effect of cotton extract on sperm morphology. Andrologia . Pp101-105.

11. Shami, S. A. (1982). A study of some pharmacological and toxicological characteristics of Flowers Caper, Master. College of Veterinary Medicine, University of Baghdad.

12. Baron, E.J.; and Fingold, S.M. (1994) Bailey and Scott's Diagnostic MicroBiology. $8^{\text {th }}$ ed. C.V. Mosby Company.

13. Drillich M.(2006) an update on uterine infections in dairy cattle; Slov Vet Res. Vol. 43 (1): 11-15.

14. Galvão N. (2012) Identifying and Treating Uterine Disease in Dairy 
$\begin{array}{llll}\text { AL-Qadisiya Journal of Vet.Med.Sci. } & \text { Vol./12 } & \text { No./1 } & 2013\end{array}$
Cows; Florida Dairy
Production.Vol. 47, Pp.21-29.
23. Sheldon, M.; Dobson, H. (2004)
postpartum uterine health in cattle, Animal Reproduction Science Vol. 82-83; pp 295-306.
15. Ebrahim, R.A.;Yadollah, A.; Peyman, S.(2012) Identification of bacterial and fungal causes of bovine abortion in Rasht region, North of Iran; International Journal of Agriculture and Crop

Sciences.Vol.,4(8), 431-433.

16. Sheldon, M.; Cronin, J.; Goetze, L.; Donofrio, G; and Schuberth, H. J. (2010) Defining Postpartum Uterine Disease and the Mechanisms of Infection and Immunity in the Female Reproductive Tract in Cattle, BiolReprod. ; 81(6): 10251032.

17. Azizunnesa ; Joy, S. D. and Faruk, M. O. (2011)Isolation and Identification of Uterine Microorganisms in Postpartum Dairy Cows, Bangladesh J Microbiol; Volume 28; Number1; pp 19-23.

18. Basheer E. B. and Taha M. B. (2008) Comparative study of some local therapeutics for endometritis in cows; Iraqi Journal of Veterinary Science. Vol.22, Pp.89-99.

19. Givens, M. D.; Marley, M.S.D. (2008) Infectious causes of embryonic and fetal mortality; Theriogenology, (4) Pp.16

20. Naoman, U. D.; Al-abidy, H.F. and Lazim, E.H. (2009) Hydrosalpinx and pyosalpinx in Iraqi local breed cows; Iraqi Journal of Veterinary Science.Vol.23, No.2, Pp.121-126.

21. Kaczmarowski, M.;Malinowski, E. and Markiewicz, H.(2004) Bacteria isolated from the uterus of cows with foetal membrane retained; National Veterinary Research Institute. 48, 33-36.

22. Azawi, O.I. (2010) uterine infection in buffalo cows: a review, Journal. Mosul, Vol.29 No.3.

24. Khashe S M. and Janda . (1998) Biochemical and Pathogenic Properties of Shewanella alga and Shewanella putrefaciens; Journal of clinical microbiology, Vol. 36, No. 3,Pp.783-787.

25. Lewis S.G. (1997) Symposium: Health Problems of the postpartum cow; Journal of Dairy Science Vol. 80, No. 5, 984-994.

26. Bondurant R.H.(2012) Inflammation in the bovine female reproductive tract, Dairy Sci.Vol.82.Pp.101-107

27. Vanroose, G.; de Kruif, A.; Van Soom ,A.( 2000) Embryonic mortality and embryo- pathogen interactions, Animal Reproduction Science Vol.60-61:Pp 131-143. .G. S،

28. Azawi O. I. , Omran S. N., Hadad, J. J. (2008) A study on postpartum metritis in Iraqi buffalo cows: bacterial causes and treatment; Reproduction in Domestic Animals.43(5):556-65.

29. Helmuth, R. and Protz, D. (1997) How to Modify Conditions Limiting Resistance in Bacteria in Animals and Other Reservoirs; Clinical Infectious Diseases. 24(1):136-8.

30. Heuer, H.; Krogerrecklenfort, E.; Wellington, E.M.H.; Egan, S.; Elsas, J.D.; Overbeek,L.; Collard, J. M.; Guillaume, G.; Karagouni, A.D.;Nikolakopoulou, T.L.; Smalla, K.(2002) Gentamicin resistance genes in environmental bacteria: prevalence and transfer Microbiology Ecology. Vol.42, Pp. 289-302.

31. Mawer, S. L. And Greenwood, D. (2012) Specific and non-specific resistance to aminoglycosides in Escherichia coli; Journal of Clinical Pathology. 31, 12-15. 


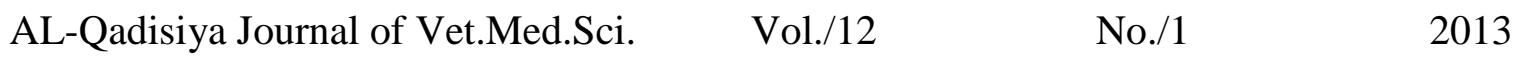

32. Tolmasky, M. E. (2009) Bacterial resistance to aminoglycosides and beta- lactams: The Tn133 transposon paradigm; Frontiers in Bioscience 5, d20-29.

33. Santos, T. M. A.; Gilbert, R. O.; Caixeta, L. S.; Machado, V. S.; Teixeira, L. M.; and Bicalho, R. C. (2009) Susceptibility of Escherichia coli isolated from uteri of postpartum cows to antibiotic and environmental bacteriophages. Part II: In vitro antimicrobial dairy activity evaluation of a bacteriophage cocktail and several antibiotics; Journal of science Dairy Vol. 93 No. 1, Pp. 105-114.

34. Liberato, R. B.; A. Canga, G.; Martin, P. T.; Salazar, M. E. (2011)Amoxicillin and Amoxicillin clavulanic acid resistance in veterinary medicine - the situation in Europe: a Review;Veterinarni Medicina, 56(10): 473-485.

35. Mitra, N.; Mohammad-Mehdi, D.; Reza, Z. M. (2012) Tribulus Terrestris L. (Zygophyllaceae) Flavonoid Compounds; International Journal of Modern Botany. 2(3): 35-39.

36. kigbo R. N., Anuagasi C. L. and Amadi J. E.(2009) Advances in selected medicinal and aromatic plants indigenous to Africa; Journal of Medicinal Plants Research Vol. 3(2), pp. 086-095.

37. Cheeke, P.R. (2001) Actual and potential applications of Yucca schidigera and Quillaja saponaria saponins in human and animal nutrition; Recent Advances in Animal Nutrition in Australia, Vol.13, Pp. 115-125.

38. Kensav, M. (2011) Studies on phytochemical screening and antibacterial activity of lantana camara linn; Plant Sciences Feed. Vol. 1 (5): 74-79.

39. Shihabudeen, M. S.; Priscilla, H.; Thirumurugan, K.(2010) Antimicrobial activity and phytochemical analysis of selected Indian folk medicinal plants; International Journal of Pharma Sciences and Research.Vol.1 (10), 430-434.

40. Menghani, E; Dwivedi, S.C.; Dubey, R.;Tyagi, R.; Masand, M.; Advani, U.(2011) Medical bioactives as antimicrobial agent. An overview; international journal of pharmaceutical research development Vol: 3(7), Pp. 24-30.

41. Kunwar, R. M.; Shrestha, K. P.; Bussmann, R. W. (2010) Traditional herbal medicine in Farwest Nepal:a pharmacological appraisal; Journal of Ethnobiology and Ethnomedicine 6:35, Pp.1-18.

42. Cowan, M.M. (1999) Plant Products as Antimicrobial Agents; Antimicrobial plant chemical.Vol. 12, No. 4, Pp. 564-582. 
AL-Qadisiya Journal of Vet.Med.Sci. $\quad$ Vol./12 No./1 2013

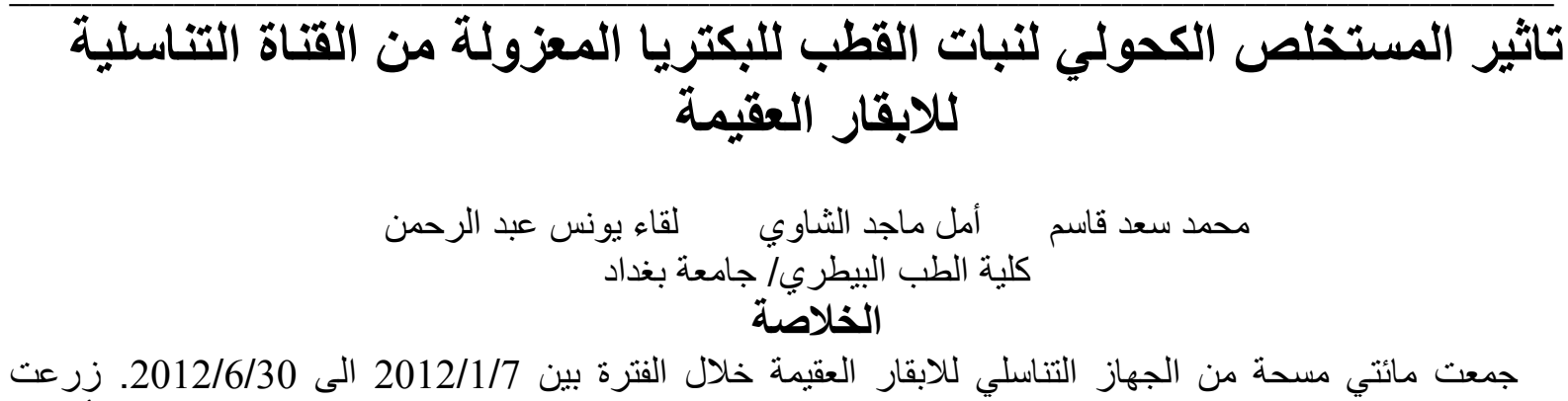

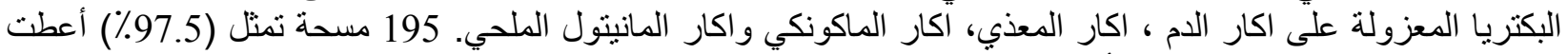

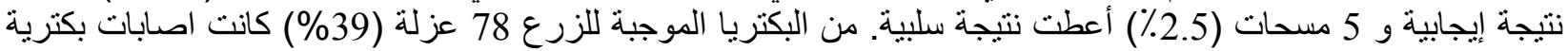

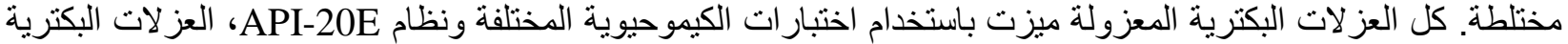

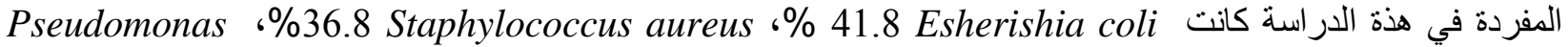
Shewanella , \%1.7 Providencia rettergi ‘\%1.7 Citrobacter braakii ‘\%17 aeruginosa Staphylococcus + \%53.8 بالنسبة الى العزلات البكترية المختلطة كانت اعلى ن 0.9 putrefaciens + Esherishia coli Pseudomonas aeruginosa+ وأقل نسبة كانت Esherishia coli aureus Citrobacter braakii

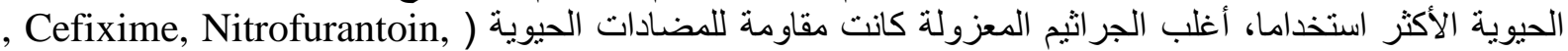
Ceftriaxone ,Nalidix acid ,Amoxicillin, Amikacin (Tetracycline, Norfloxacin, (Amoxicillin and من جهة اخرى نلاحظ حساسيتها للمستخلص الكحولي لنبات القطب ( الثمار) للتر اكيز.Clavulanic acid), Gentamycin) 